\title{
Effect of temperature on sex expression in onion
}

\section{(Allium cepa L.)}

Q. P. van der Meer and J. L. van Bennekom

Institute for Horticultural Plant Breeding (IVT), Wageningen, the Netherlands

Key words: Onion; Allium cepa; temperature; sex expression; male sterility

\section{Summary}

The temperature effect on sex expression of lines and hybrids originating from Rijnsburg and Wolska was investigated.

Many populations showed an unexpected high number of male-sterile plants at 14 and $17{ }^{\circ} \mathrm{C}$. Induction takes place in the early part of the bolting period.

Many Rijnsburg A and B lines appeared to be completely stable at different temperatures. On the other hand many other Rijnsburg B lines and also many Wolska lines were more or less unstable.

\section{Introduction}

Male sterility in onion was discovered in 1925 (Jones \& Emsweller, 1936). It was found by Jones \& Clarke (1943) that it is based on a combination of one recessive major gene $(\mathrm{ms})$ and a certain type of cytoplasm ( $S$-plasma). Only plants of the idiotype Smsms are male sterile. The Smsms idiotype can be maintained generatively by pollinating it with the Nmsms idiotype ( $N=$ normal plasm). Plant breeders call these idiotypes $\mathrm{A}$ line and $\mathrm{B}$ line, respectively.

Recently plants were found showing male fertility at high and male sterility at low temperatures (van der Meer \& van Bennekom, 1969). These occurred in potential A lines as well as in potential B lines. This phenomenon may give rise to segregation ratios being very obviously in contradiction with the theory of Jones \& Clarke (1943).

In order to learn more about this effect of temperature on sex expression it has been investigated whether there is a critical temperature and at which stage of development the sex expression is influenced. At the same time many populations were screened to find material completely resistant and material completely susceptible to the temperature effect.

Hereafter a description is given of the above mentioned research.

\section{Material and methods}

Lines of the Dutch variety Rijnsburg and the Polish variety Wolska were used for the experiments. 
Different temperature treatments were realized in the greenhouses of the phytotron. Details of these treatments are given in combination with the results of the experiments.

\section{Critical temperature}

The effect of temperature is shown very clearly when temperatures of $14{ }^{\circ} \mathrm{C}$ and $23{ }^{\circ} \mathrm{C}$ are given (van der Meer \& van Bennekom, 1969). So somewhere between these values a critical temperature may be found above which susceptible plants will be male-fertile and below which these plants will be male-sterile.

In an experiment plants which had just started bolting were placed at a range of constant temperatures. The results are given in Table 1.

It can be seen that the percentage of male-fertile plants is higher at higher temperatures. Obviously the critical temperature lies near $17^{\circ} \mathrm{C}$.

None of the populations mentioned in Table 1 does show $100 \%$ sterile plants at $14{ }^{\circ} \mathrm{C}$ and $100 \%$ fertile plants at $23{ }^{\circ} \mathrm{C}$. So these populations are only partially susceptible to the temperature effect.

Table 1. Number of male-sterile (ms) and male-fertile (mf) plants in onion populations when brought from the open to different temperatures directly at the beginning of the bolting period and to $14^{\circ} \mathrm{C}$ 3 and 6 weeks after the beginning of bolting. 1975 .

\begin{tabular}{|c|c|c|c|c|c|c|c|c|c|c|c|c|}
\hline \multirow{4}{*}{$\begin{array}{l}\text { Wolska 'A'1 } \\
\text { population } \\
\text { No }\end{array}$} & \multicolumn{8}{|c|}{ Temperature from the beginning of bolting ${ }^{2}$} & \multirow{3}{*}{\multicolumn{2}{|c|}{$\begin{array}{l}14{ }^{\circ} \mathrm{C} \text { three } \\
\text { weeks after } \\
\text { beginning } \\
\text { of bolting }\end{array}$}} & \multirow{3}{*}{\multicolumn{2}{|c|}{$\begin{array}{l}14{ }^{\circ} \mathrm{C} \text { six } \\
\text { weeks after } \\
\text { beginning } \\
\text { of bolting }{ }^{2}\end{array}$}} \\
\hline & \multicolumn{2}{|c|}{$14^{\circ} \mathrm{C}$} & \multicolumn{2}{|c|}{$17^{\circ} \mathrm{C}$} & \multicolumn{2}{|c|}{$20^{\circ} \mathrm{C}$} & \multicolumn{2}{|c|}{$23^{\circ} \mathrm{C}$} & & & & \\
\hline & \multirow{2}{*}{$\mathrm{ms}$} & \multirow[t]{2}{*}{$\mathrm{mf}$} & \multirow[t]{2}{*}{$\mathrm{ms}$} & \multirow[t]{2}{*}{$\mathrm{mf}$} & \multirow[t]{2}{*}{$\mathrm{ms}$} & \multirow[t]{2}{*}{$\mathrm{mf}$} & \multirow[t]{2}{*}{$\mathrm{ms}$} & \multirow[t]{2}{*}{$\mathrm{mf}$} & & & & \\
\hline & & & & & & & & & $\mathrm{ms}$ & $\mathrm{mf}$ & ms & $\mathrm{mf}$ \\
\hline 1 & 4 & 9 & 0 & 13 & 0 & 12 & 0 & 5 & 1 & 5 & 1 & 6 \\
\hline 2 & 8 & 6 & 3 & 11 & 5 & 5 & 0 & 12 & 9 & 5 & 5 & 9 \\
\hline 3 & 8 & 5 & 2 & 11 & 0 & 14 & 0 & 14 & 7 & 6 & 3 & 10 \\
\hline 4 & 7 & 4 & 2 & 11 & 1 & 7 & 5 & 6 & 5 & 2 & 7 & 1 \\
\hline 5 & 6 & 5 & 9 & 5 & 2 & 7 & 4 & 9 & 6 & 8 & 3 & 8 \\
\hline 6 & 8 & 6 & 5 & 2 & 3 & 4 & 3 & 11 & - & - & - & - \\
\hline 7 & 4 & 9 & 1 & 7 & 0 & 12 & 0 & 8 & - & - & - & - \\
\hline 8 & 5 & 3 & 5 & 6 & 4 & 3 & 6 & 4 & - & - & - & - \\
\hline 9 & 6 & 1 & 7 & 0 & 3 & 4 & 2 & 4 & 5 & 1 & 2 & 5 \\
\hline 10 & 4 & 3 & 0 & 7 & 0 & 5 & 0 & 7 & 4 & 3 & 1 & 8 \\
\hline 11 & 1 & 11 & 0 & 12 & 0 & 5 & 0 & 5 & - & - & - & - \\
\hline Total & 61 & 62 & 34 & 85 & 18 & 78 & 20 & 85 & 37 & 30 & 22 & 47 \\
\hline$\%$ ms plants & 50 & & 29 & & 19 & & 19 & & 55 & & 32 & \\
\hline
\end{tabular}

1 Wolska ' $A$ ' indicates the offspring of a male-sterile Wolska plant pollinated by a male-fertile Wolska plant, in other words a potential A line.

${ }^{2} \mathrm{~ms}=$ number of male sterile plants; $\mathrm{mf}=$ number of male fertile plants. 


\section{EFFECT OF TEMPERATURE ON SEX EXPRESSION IN ONION}

Table 2. Behaviour of Rijnsburg lines stable (pair 1 and A line of pair 2) and unstable (B line of pair 2) in respect of the temperature effect on sex expression $(\mathrm{ms}=$ number of male sterile plants; $\mathrm{mf}=$ number of male fertile plants). 1972.

\begin{tabular}{|c|c|c|c|c|c|c|c|c|}
\hline & \multicolumn{4}{|c|}{ Line pair 1} & \multicolumn{4}{|c|}{ Line pair 2} \\
\hline & \multicolumn{2}{|c|}{ A line } & \multicolumn{2}{|c|}{ B line } & \multicolumn{2}{|c|}{ A line } & \multicolumn{2}{|c|}{ B line } \\
\hline & $\mathrm{ms}$ & $\mathrm{mf}$ & $\mathrm{ms}$ & $\mathrm{mf}$ & $\mathrm{ms}$ & $\mathrm{mf}$ & $\mathrm{ms}$ & $\mathrm{mf}$ \\
\hline In the open & 395 & 0 & 0 & 392 & 392 & 0 & 39 & 352 \\
\hline $23{ }^{\circ} \mathrm{C}$ & 7 & 0 & 0 & 6 & 3 & 0 & 0 & 6 \\
\hline $14^{\circ} \mathrm{C}$ & 4 & 0 & 0 & 7 & 5 & 0 & 5 & 0 \\
\hline
\end{tabular}

\section{Influence of the stage of development}

In the experiment as described before also plants were brought from the open to $14{ }^{\circ} \mathrm{C} 3$ and 6 weeks after the beginning of bolting. It can be seen from Table 1 that the influence of the temperature was maximal when the plants were exposed to $14{ }^{\circ} \mathrm{C}$ at the beginning of the bolting period or three weeks after the beginning. The effect of low temperature decreased when plants were placed at $14{ }^{\circ} \mathrm{C} 6$ weeks after the beginning of bolting.

\section{Possibilities of selection for stable and unstable sex expression}

A number of Rijnsburg A and B lines were screened for stability of sex expression at low $\left(14{ }^{\circ} \mathrm{C}\right)$ and high temperature $\left(20\right.$ or $\left.23{ }^{\circ} \mathrm{C}\right)$. It was easy to distinguish stable lines from unstable ones. An example is given in Table 2. Obviously the B line of pair 1 is 'resistant' and the B line of pair 2 is 'susceptible' to the temperature effect. In Rijnsburg the unstability only occurs in B lines and not in A lines. In Wolska the situation is more complicated.

A small number of lines were completely male-fertile at high temperature and completely male-sterile at low temperature (B line of pair 2 of Table 2). So these lines appeared to be completely unstable in respect of sex expression.

\section{Discussion}

It should be noted that in the Netherlands temperatures between 14 and $17{ }^{\circ} \mathrm{C}$ occur very often in the open during spring and summer. Therefore it is obvious that, depending on the actual temperatures, the sex expression of unstable plants can be either male sterile or male fertile. This is in good accordance with the results of field observations.

Until now two very pronounced influences on the sex expression of onions have been found, namely the temperature effect as described in this article and the GA effect as described by van der Meer \& van Bennekom (1973).

An intriguing question is if the sex expression is mediated by GA and if the GA content of an onion plant is influenced by temperature. An indication for a relation- 
ship between the temperature effect and the GA effect is that the induction phase for both effects is the beginning of the bolting period.

In our research program we are paying now attention to the above mentioned relationship.

\section{References}

Jones, H. A. \& A. E. Clarke, 1943. Inheritance of male sterility in the onion and the production of hybrid seed. Proc. Am. Soc. hort. Sci. 43: 189-194.

Jones, H. A. \& S. L. Emsweller, 1936. A male sterile onion. Proc. Am. Soc. hort. Sci. 34: 582-585. Meer, Q. P. van der \& J. L. van Bennekom, 1969. Effect of temperature on the occurrence of male sterility in onion (Allium cepa L.). Euphytica 18: 389-394.

Meer, Q. P. van der \& J. L. van Bennekom, 1973. Gibberellic acid as a gametocide for the common onion (Allium cepa L.). Euphytica 22: 239-243. 